\title{
Peningkatan Keterampilan Pengelolaan Keuangan Rumah Tangga Nelayan Palabuhanratu
}

\section{Improving the Financial Management Skills of Palabuhanratu Fishermen's Household}

\author{
Tuti Kurniaㅜ; Imam Abdul Aziz²; Maya Apriana3; Romi Apriliansyah"; Aldi Wijaya ${ }^{5}$ \\ 1,5Program Studi Ekonomi Syariah Universitas Djuanda Bogor, Jl. Tol Jagorawi No.1 Ciawi Bogor, Jawa \\ Barat 16720, e-mail: tuti.kurnia@unida.ac.id \\ 2,3,4Program Studi Perbankan Syariah Universitas Djuanda Bogor, Jl. Tol Jagorawi No.1 Ciawi Bogor, Jawa \\ Barat 16720
}

(Diterima: 20-12-2020; Ditelaah: 12-04-2021; Disetujui: 30-10-2021)

\begin{abstract}
Abstrak
Pengabdian kepada masyarakat ini bertujuan untuk meningkatkan keterampilan pengelolaan keuangan bagi rumah tangga nelayan di Palabuhanratu. Peningkatan keterampilan pengelolaan keuangan nelayan Palabuhanratuakan membantu penurunan perilaku konsumtif kelompok nelayan pada saat panen raya dan mengurangi perilaku meminjam uang pada saat paceklik. Metode pengabdian yang dilakukan adalah dengan pendekatan Participatory Action Research (PAR), yang melibatkan langsung nelayan dalam proses pelatihan dan pendampingan. Jumlah nelayan yang mengikuti kegiatan ini sebanyak 16 nelayan yang berada diwilayah Palabuhanratu. Hasil dari kegiatan pengabdian ini adalah meningkatnya keterampilan nelayan dalam bidang pengelolaan keuangan yang meliputi pencatatan asset, pencatatan pemasukan dan pengeluaran, identifikasi pengeluaran dan identifikasi pemasukan serta pencatatan untuk menabung. Sekitar 70 persen nelayan yang mengikuti pelatihan dapat melakukan pencatatan sederhana.
\end{abstract}

Kata kunci: Pengelolaan Keuangan, Palabuhanratu, Nelayan,

\begin{abstract}
This devotion sociaty activity aims to improve financial management skills for fishing households in Palabuhanratu. Improving the financial management skills of the fishermen of Palabuhanratu will help reduce the consumptive behavior of fishermen groups during the harvest season and reduce the behavior of borrowing money during famine. The service method used is the Participatory Action Research (PAR) approach, which involves fishermen directly in the training and mentoring process. The number of fishermen who participated in this activity was 16 fishermen in the Palabuhanratu area. The result of this training is an increase in fishermen's skills in the field of financial management which includes asset recording, recording income and expenses, identification of expenses and identification of income and recording for saving. Around 70 percent of fishermen that following the training able to recording of financial management.
\end{abstract}

Keywords: Finnacial Management, Fishermen, Palabuhanratu

\section{PENDAHULUAN}

Nelayan merupakan salah satu profesi yang memiliki pendapatan yang tidak teratur baik secara jumlah dan waktunya. Pendapatan nelayan memiliki siklus yang berbeda tergantung dari masanya yaitu masa paceklik dan panen raya. Nelayan dapat digolongkan menjadi 3 kelompok yaitu kelompok nelayan besar/juragan, nelayan kecil dan nelayan buruh (Rahman dan Alhifni, 2018; Kurnia dan alhifni, 2018). Pendapatan nelayan di Palabuhanratu pada saat panen raya bagi nelayan juragan mencapai 154 juta rupiah, nelayan kecil 11 juta rupiah dan nelayan buruh tergantung pemberian dari nelayan 
juragan atau nelayan kecil. Sementara itu pada saat paceklik pendapatan mereka menurun drastis biasa mencapai 900 ribu rupiah sampai dengan 0 rupiah (Rahman dan Alhifni, 2018).

Selain dari pendapatan yang berfluktuatif, karakteristik nelayan terkait dengan penggunaan uang juga menjadi hal yang harus diperhatikan. Perilaku nelayan dalam penggunaan atau pengelolaan uang cenderung konsumtif Perilaku nelayan pada saat panen raya Palabuhanratu memiliki kebiasaan untuk belanja barang atau jasa bahkan yang tidak dibutuhkan. Sementara itu, pada saat paceklik maka nelayan akan meminjam uang (Kurnia dan Safitri, 2020). Perilaku melakukan pinjaman pada saat paceklik memberikan dampak ikutan yaitu semakin sulitnya kehidupan ekonomi nelayan, karena sebagian besar nelayan meminjam dari rentenir dengan tingkat bunga yang cukup tinggi. Kombinasi antara fluktuatifnya pendapatan dan perilaku penggunaan atau pengelolaan keuangan menjadi salah satu sebab nelayan berada pusaran kemiskinan (Kurnia dan Safitri, 2020).

Menurut Devas (2007:279) pengelolaan keuangan berarti mengurus dan mengatur keuangan dengan prinsip-prinsip pengelolaan keuangan. Secara umum tujuan dari pengelolaan keuangan adalah: mencapai target dana tertentu di masa yang akan datang, melindungi dan meningkatkan keuangan yang dimiliki, mengatur arus kas pemasukan dan pengeluaran, mengatur utang piutang, membuat struktur permodalan dan mengurangi pengeluaran yang tidak prioritas. Pengelolaan keuangan meliputi pengelolaan keuangan pribadi, pengelolaan keuangan keluarga, dan pengelolaan keuangan perusahaan. Pengelolaan keuangan merupakan bagian penting dalam mengatasi masalah ekonomi, baik masalah ekonomi individu, keluarga maupun perusahaan. Adapun ruang lingkup pengelolaan keuangan bagi nelayan meliputi: pengelolaan keuangan rumah tangga nelayan dan pengelolaan keuangan untuk kebutuhan melaut.

\section{METODE PELAKSANAAN}

Metode pendekatan pelaksanaan pengabdian kepada masyarakat yang digunakan dalam kegiatan ini adalah Participatory Action Research (PAR). PAR adalah sebuah kegiatan pengabdian masyarakat berbentuk riset yang dilakukan dengan partisipasi masyarakat dalam satu lingkup sosial atau komunitas untuk membuat aksi perubahan ke arah yang lebih baik. Dalam metode PAR peneliti melakukan inkulturisasi atau menyatu dengan masyarakat, tidak memisahkan diri dan bekerjasama dengan warga. Metode PAR selain memiliki luaran publikasi hasil riset dan rekomendasi untuk riset berikutnya, juga memiliki luaran perubahan situasi yang lebih baik di dalam kehidupan masyarakat baik dalam peningkatan pengetahuan dan peningkatan kemampuan warga. Pendekatan dalam PAR lebih bersifat kualitatif, namun data-data yang bersifat kuantitatif tetap bisa digunakan, dengan catatan kuantifikasi yang dilakukan hanya sebagai alat bantu dan tidak mengurangi fenomena sosial yang terjadi. Peserta kegiatan ini adalah sebanyak 16 
nelayan yang terkategori nelayan kecil yang berdomisili diwilayah Palabuhanratu. Metode pelaksanaannya dilakukan dengan pelatihan dan pendampingan.

\section{HASIL DAN PEMBAHASAN}

\section{Hasil Kegiatan Pengabdian Kepada Masyarakat}

Kegiatan pengabdian kepada masyarakat dilaksanakan di Palabuhanratu yang ditujukan untuk mitra nelayan kecil dalam kelompok nelayan TUSLA yang diketua oleh bapak Enjang Soma. Permasalahan yang dihadapi mitra adalah pengelolaan pendapatan nelayan yang cenderung fluktuatif, dimana pendapatan tinggi pada saat panen dan pendapatan minimal atau rendah pada saat paceklik. Selain itu, perilaku konsumtif nelayan kecil pada saat panen raya mendorong nelayan semakin sulit pada saat paceklik. Hal lainnya adalah selama ini sistem pembagian hasil melaut nelayan masih dilakukan tanpa pencatatan dan tanpa melihat pengeluaran untuk kegiatan melaut.

Adapun salah satu solusi untuk menyelesaikan masalah tersebut adalah dengan meningkatkan keterampilan dalam melakukan pengelolaan keuangan. Peningkatan keterampilan nelayan dalam mengelola keuangan dilakukan dengan menyelenggarakan pelatihan pengelolaan keuangan. Pelatihan pengelolaan keuangan disusun sesederhana mungkin agar dapat dipahami dan dipraktikan dengan baik oleh nelayan yang memiiliki tingkat pendidikan yang cukup beragam.

Materi yang disampaikan meliputi lima bagian yaitu pengenalan konsep dasar dari pengelolaan keuangan, pencatatan asset keuangan, pencatatan pemasukan dan pengeluaran, identifikasi pemasukan/penerimaan, identifikasi pengeluaran dan pencatatan untuk menabung. Pelatihan dilakukan di Palabuhanratu pada tanggal 21-22 Desember 2021. Adapun tahapan yang dilakukan untuk melakukan kegiatan pelatihan tersebut meliputi 4 tahapan: tahapan persiapan, tahapan analisis kebutuhan nelayan, tahapan pelaksanaan pelatihan dan tahapan evaluasi kegiatan pelatihan.

Tahapan persiapan pelatihan yang dilakukan melalui persiapan modul, dan poster untuk peraga. Persiapan modul dilakukan dengan menganalisis kebutuhan nelayan dengan menelaah materi-materi yang bersesuaian dengan kebutuhan nelayan. Kemudian setelah disusun menjadi modul maka dibuatkan poster-poster sebagai alat peraga bagi kegiatan pelatihan. Modul untuk pelatihan disusun berdasarkan hasil penelitian yang dilakukan terhadap nelayan pada tahun 2018 dan 2019. Adapun posterposter peraga pembantu kegiatan pelatihan terdiri dari 2 yaitu poster pertama yang menggambarkan materi pengelolaan keuangan secara keseluruhan yang dapat dilihat pada gambar 1 . 


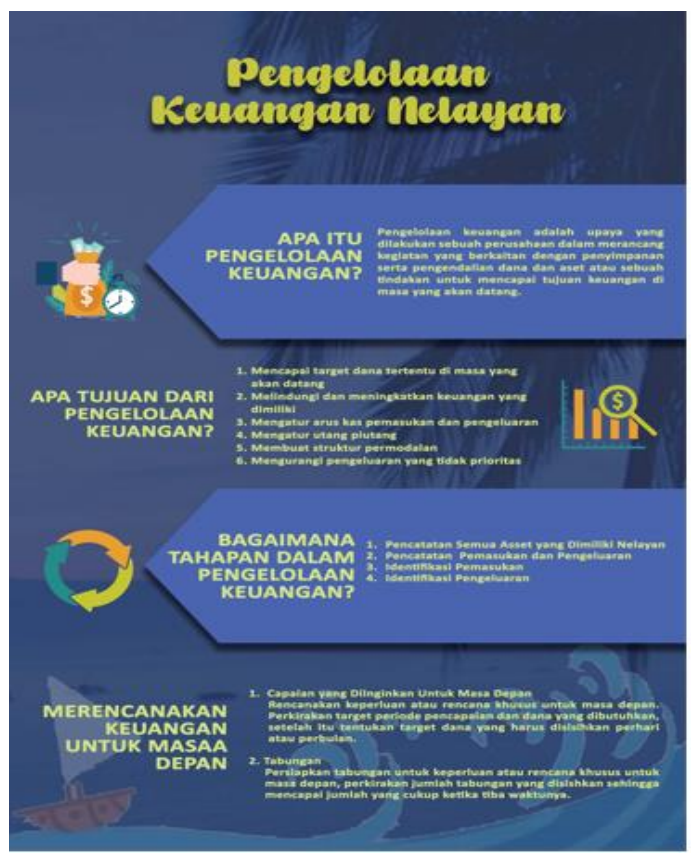

Gambar 1. Poster Konsep Pengelolaan Keuangan

Selanjutnya pada poster kedua sebagai alat bantu untuk penjelasan tahapan tahapan kegiatan pengelolaan keuangan. Poster ini diharapkan dapat membantu untuk memudahkan nelayan menemukan poin-poin penting dari kegiatan pelatihan pengelolaan keuangan.

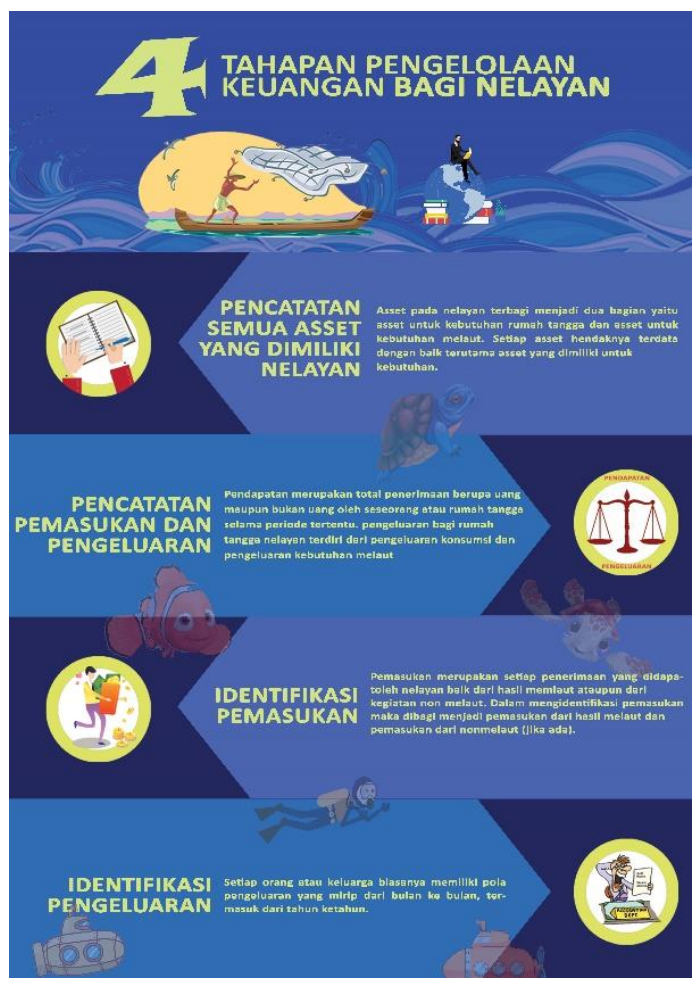

Gambar 2. Poster Tahapan Pengelolaan Keuangan 
Tahapan selanjutnya adalah analisis kebutuhan nelayan, tahapan ini dilakukan melalui wawancara dengan nelayan pada tanggal 21 Desember tahun 2021. Hal ini dilakukan untuk menyesuaikan jika ada tambahan-tambahan atau pengurangan materi yang akan disampaikan pada saat pelatihan. Pada tahapan ini juga dilakukan untuk mengecek kesesuaian kembali materi pada modul dengan kebutuhan nelayan saat ini. Gambar 3 menunjukkan kondisi dan situasi dari wawancara yang dilakukan.

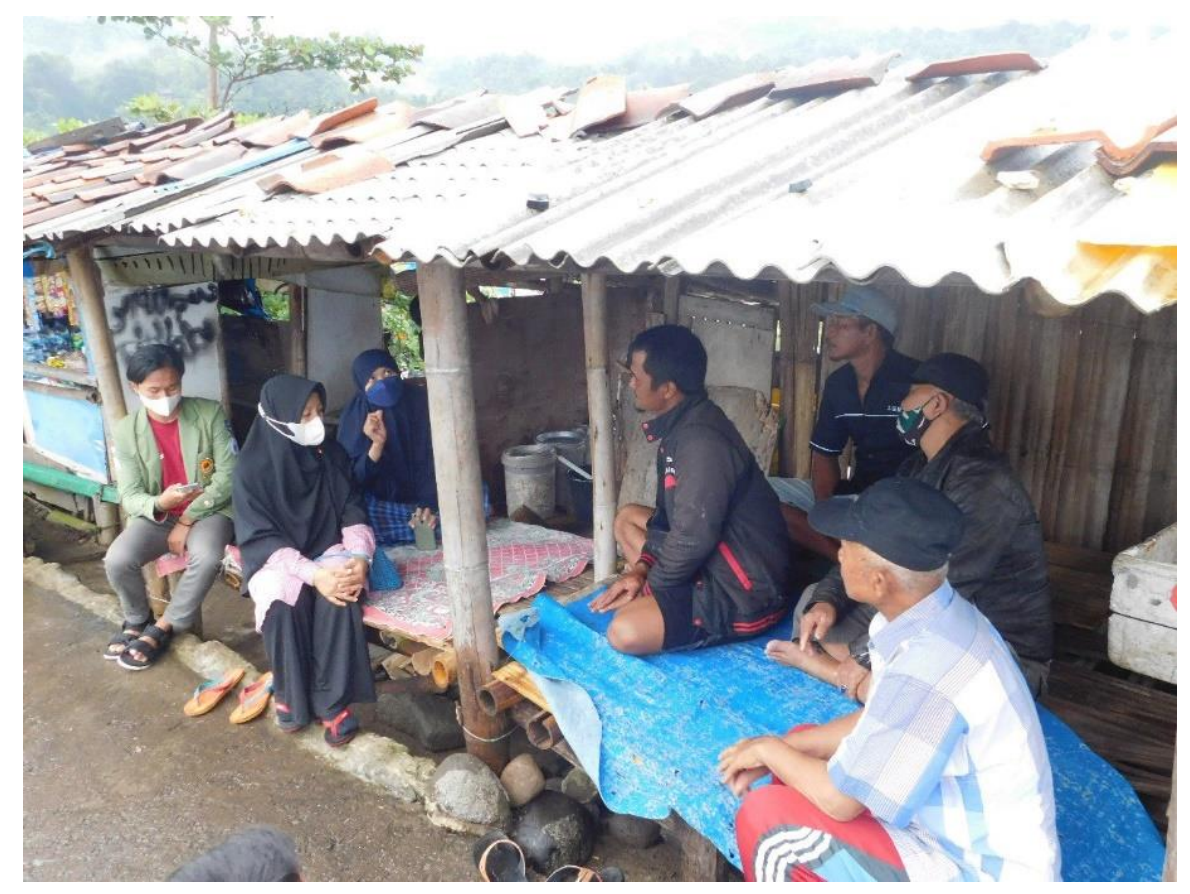

Gambar 3. Wawancara Pra Pelatihan

Adapun hasil dari wawancara dari pra pelatihan menunjukkan bahwa secara umum materi yang telah disusun pada modul telah sesuai dengan kebutuhan nelayan. Nelayan yaitu bapak Yogi menyampaikan bahwa mereka mempraktikan pembagian hasil melaut sesuai dengan pembagian sama rata berdasarkan hasil yang mereka peroleh tanpa melakukan pencatatan baik pemasukan maupun pengeluaran.

Tahapan ketiga merupakan puncak dari kegiatan yaitu pelaksanaan kegiatan pelatihan pengelolaan keuangan. Acara ini dihadiri oleh 16 Nelayan, yang dimulai pada pukul 07.30 sampai dengan 12.00 wib yang diselenggarakan di Grand Inna Samudra Beach Hotel Palabuhanratu. Narasumber pada pelatihan pengelolaan keuangan ini adalah Ibu Tuti Kurnia, SP., M.Si yang merupakan dosen Ekonomi Syariah, Fakultas Ekonomi Islam, Universitas Djuanda. Narasumber merupakan ketua peneliti dari penelitian tentang nelayan di Palabuhanratu dan Pangandaran selama dua tahun yaitu pada tahun 2018 dan 2019. Kegiatan pengabdian merupakan salah satu kegiatan hilirisasi atas hasil penelitian tersebut. Penelitian tersebut adalah penelitian "Model Pembiayaan Mikro Bagi Nelayan Melalui LKMS dengan Jaminan Asuransi Syariah. 


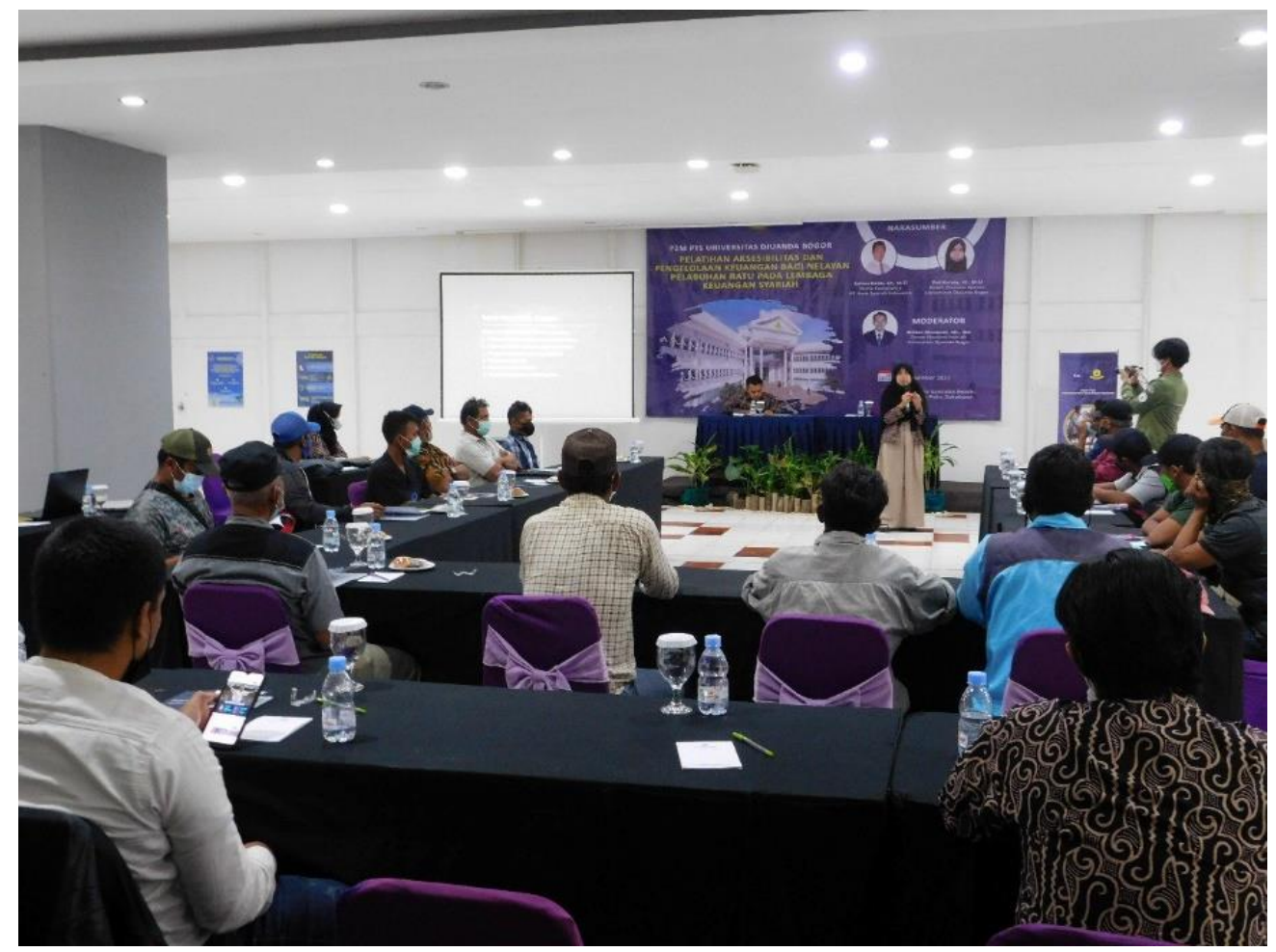

Gambar 4. Pelaksanaan Kegiatan Pelatihan Pengelolaan Keuangan Nelayan Pelabuhan Ratu

Hasil dari kegiatan ini adalah meningkatnya keterampilan pengelolaan keuangan nelayan terutama dalam kegiatan-kegiatan pencatatan-pencatatan keuangan. Sekitar 60 persen nelayan mulai ada perubahan persepsi dari awalnya tidak mengangga penting pencatatan menjadi merasa harus mulai mencoba untuk melakukan pencatatanpencatatan pada aktivitas keuangan yang nelayan lakukan, terutam pada aktivitas melaut. Pembagian hasil dari tangkapan akan mulai memperhatikan pengeluaranpengeluaran yang telah dilakukan sehingga, tidak hanya setelah memperoleh pendapatan kemudian dibagi rata bagi nelayan yang ikut melaut.

Tahap terakhir dari kegiatan ini adalah evaluasi pelatihan. Evaluasi dilakukan dengan mengadakan pre test dan post test bagi nelayan peserta pelatihan. Pada awal pre test terdapat sekitar 10 persen dari peserta yang memahami yang ditanyakan, dengan sekitar 80 persen benar dari 100 persen pertanyaan yang diajukan dalam pre test. Setelah mengikuti pelatihan dan dilakukan post test maka terdapat 70 persen peserta dapat menjawab dengan benar keseluruhan pertanyaan. Selain itu, sekitar 70 persen nelayan juga dapat melakukan pencatatan sederhana pengelolaan keuangan untuk melaut. 


\section{KESIMPULAN}

Kegiatan pengabdian kepada masyarakat yang dilakukan adalah kegiatan pelatihan pengelolaan keuangan bagi nelayan di Palabuhanratu. Kegiatan dilaksanakan pada tanggal 21-22 Desember 2021 yang diikut oleh 16 nelayan kecil yang tergabung dalam kelompok nelayan Tusla. Kegiatan dilaksanakan melalui 4 tahapan yaitu persiapan, analisis kebutuhan nelayan, pelaksanaan pelatihan dan evaluasi pelatihan. Hasil dari kegiatan pengabdian adalah terdapat peningkatan keterampilan nelayan kelompok Tusla yaitu sekitar 70 persen dari nelayan kelompok Tusla yang mengikuti pelatihan dapat melakukan pencatatan pengelolaan keuangan sederhana.

\section{UCAPAN TERIMA KASIH}

Ucapan terima kasih kami sampaikan kepada Kementerian Pendidikan dan Kebudayaan Nasional atas hibah untuk pendanaan kegiatan pengabdian kepada masayarakat. Selain itu, kami mengucapkan terimakasih kepada Universitas Djuanda dan DRPM Universitas Djuanda.

\section{DAFTAR PUSTAKA}

Devas. 2007. Keuangan Pemerintah Daerah di Indonesia. Penerbit Gramedia Pustaka Utama, Jakarta.

Kurnia, T dan Alhifni, A (2018). IJMS Alternatif Model Pembiayaan Syariah Bagi Nelayan Kecil Di Indonesia. Prosiding Semnas PPM: Vol 1, No.1 Hal 714-728.

Kurnia, T dan Safitri, D (2020). Model Of Distribution of Zakah Fund For Fishermen Through IMFS. Prosiding: International TVET, Academic and Research Conference 20 February 2020, Polytechnic Nilai Negeri Sembilan, Malaysia. Hal. 106-117

Rahman, A, A dan Alhifi A., (2018) Analisis Kebutuhan Nelayan Terhadap Pembiayaan LKMS., Jurnal Syarikah: Vol. 4 No, 2 Hal 152-162. 